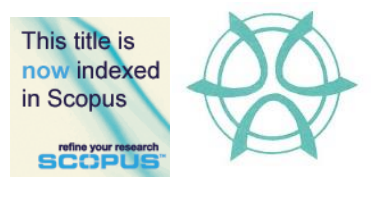

PLANNING MALAYSIA:

Journal of the Malaysian Institute of Planners

VOLUME 15 ISSUE 1 (2017), Page 1 - 12

\title{
SUSTAINABILITY CONCEPTS IN MALAY AND ACEH TRADITIONAL HOUSES
}

\author{
Noor Hanita Abdul Majid ${ }^{1}$, Zuraini Denan ${ }^{2}$, Zaiton Abdul Rahim ${ }^{3}$, Norwina Mohd \\ Nawawi ${ }^{4}, \&$ Siti Norfakiah Hazman ${ }^{5}$ \\ 1,2,3,4,5 Kulliyyah of Architecture and Environmental Design, \\ INTERNATIONAL ISLAMIC UNIVERSITY MALAYSIA
}

\begin{abstract}
The migration of people between Acheh and Malaysia can be seen in sporadic settlements in the northern regions. Both communities share Islam as a religion and might have similarities in culture, ethics and the environment. Due to the Islamic influences in both Malay and Aceh community, it is predicted that the traditional houses in both locations are manifestations of the sustainable concept of hablumminallah, hablumminannas and hablumminal'alam. This concept can be analysed in terms of the Islamic implementations of hablumminallah, social beliefs, and activities in the relationship between man and man (hablumminannas) and climatic influences in the relationship between man and environment (hablumminal'alam). Hence, this paper intends to investigate the implementation of the three concepts in the Malay and Aceh houses. The research methodologies employed are observation (through site visits), pictorial analysis and detail evaluations on the components of the houses. Analysis conducted on Rumah Kutai (RK), Perak and Rumoh Aceh (RA) suggest the realization of the three mentioned sustainable concepts in the houses. In conclusion, the overall findings confirmed the sustainability concepts adopted in the RK and RA through adhering to Islamic guidelines, socio-cultural and climatic aspects.
\end{abstract}

Keyword: traditional house, sustainable concept, social beliefs and climate

Date Received: $30^{\text {th }}$ April 2016

Date of Acceptance: $30^{\text {th }}$ October 2016 
Noor Hanita Abdul Majid, Zuraini Denan, Zaiton Abdul Rahim, Norwina Mohd Nawawi, \& Siti Norfakiah

Concepts in Malay and Aceh Traditional Houses

\section{INTRODUCTION}

"And (remember) when your Lord said to the angels: "Verily, I am going to place (of mankind) a khalifah (caliph) on earth" [Al Baqarah 2:30].

As a caliph, part of man responsibilities as a vicegerent on earth is to manage the world and contribute to the sustainability of the environment. The needs of living drive man to create a shelter to fulfil ever changing and increased necessities. And in turn, the shelter serves the needs of man to perform their duties to the Creator, man, and the environment. The needs, culture, and environment always play a major role in shaping the architecture of a place or vernacular architecture. Vernacular architecture is the most pronounced interpretation of the needs, culture, and environment of the people. It had been widely discussed that the traditional architecture (as a form of vernacular architecture) of each region had been designed responsively to the local climate. (Hutchinson, 2002) asserted that a region could often be clearly recognized by the character of its housing. Hence, houses as a basic shelter reflect critical factors such as climate, materials, economics and cultural background of a given environment.

The cultural values of Malays and Acehnese have always been identified as values associated with Islam that is portrayed in the vernacular architecture of this region; for example, Rumoh Aceh (RA) and traditional Malay house. Since vernacular architecture is a local expression, it is also a sustainable solution for a given environment. VerSus (2006), a European research project, affirmed the tendency of a direct connection between sustainable and vernacular architecture based on the research and reviews. Again, sustainability and architecture are inseparable, and man as the vicegerent on earth has the responsibility to continue holding to the Islamic spirituality. Spahic (2009) discussed the concepts of sustainability in Islamic architecture, deliberating on the significance of the concepts about man and environment. He has come to a conclusion on the coexistence between people and environment; and reckons that sustainability is a part of Islamic Architecture. In reaction to these propagations on the relationship of vernacular architecture, sustainability, and Islamic architecture, this paper will elaborate on concepts of sustainability in the relationship between man and God, between man and man, and also between man and environment which was also known as hablumminallah, hablumminannas, and hablumminal'alam respectively. The discussion of this paper will discuss these concepts implementations in traditional Malay houses in the form of Rumah Kutai (RK), Perak and traditional Aceh house/Rumoh Aceh (RA).

\section{RESEARCH BACKGROUND}

Sustainability in Islam had been observed through having a good relationship which can be referred to as hablumminallah (the relationship between man and Allah (God), hablumminannas (the relationship between man and man) and 
PLANNING MALAYSIA

Journal of the Malaysia Institute of Planners (2017)

hablumminal'alam (the relationship between man and environment). This triangular concept of relations between God, men, and the environment had been viewed as a profound element in the formation of traditional houses, in particular, the traditional Malay and Aceh houses.

The first concept, hablumminallah can be seen based on the implementation of Islamic teachings in all aspects of life. The concept of hablumminallah is not only possible to be translated into physical aspect but most importantly to be felt spiritually. The traditional house of Malay and Aceh are expressions of iman (belief of God). The traditional houses of the Malays symbolized the Malay culture which is rooted with the Islamic teachings and practices. Whereas, the traditional house of Aceh is also known as a form of architecture that reflect the faith of people in Aceh (Nas \& Iwabuchi, 2008).

The terms hablumminannas means the relationship between man and man that involves culture and social activities. The house is built not only for the purpose of life, for shelter and to cater the basic needs, but it is also built to strengthen the relationship between the family members and the surrounding neighbourhood. Kamal (2015) states that the traditional Aceh house reflected the cultural and environmental sentiment of a place and community. He added, the society`s or individual's belief and environmental condition have a significant influence on the architecture of a house, as seen in the architecture of RA.

The concept of hablumminal'alam (the relationship between man and environment) in architectural perspective can be witnessed through the site and climatic considerations in the house design. The manifestations of the site and climatic factors are clearly seen in the design of the RK and RA in terms of siting, type of construction, architectural elements and features.

The relationship of Aceh and Malaysia can be traced back to the spread of Islam and Dutch colonialisation. The traces of the migration can be seen in sporadic settlements in the northern regions, with the largest being settlements in Yan, Kedah, and Kampong Acheh in Pulau Pinang and Perak. These three states in the northern part of Peninsular Malaysia are the closest to Aceh by their geographical location. Kamaruzzaman, Ruzman and Mohd Yakub (2012) discuss the influence of Aceh in Penang that started in the 15th century in terms of the Malay identity. History has recorded that in the year 1567 - 1585 M, Sultan Alauddin Mansur Syah I, the son of Sultan Mansur Syah 1 from Aceh was brought to the throne as the second Sultan of Perak State.

The relationship between Aceh and the mentioned places in Malaysia is part of the historical and social development. Hence, it is hypothesized that the traditional houses of the long roof type for these regions may share the same basic considerations in architectural design. As for RK and RA, both not just represent the architecture features of Malay and Acehnese culture and the traditional living of the people, but at the same time they also have been designed with particular regard to suit to the local tropical climate. The hypothesis forwarded by Seri 
Noor Hanita Abdul Majid, Zuraini Denan, Zaiton Abdul Rahim, Norwina Mohd Nawawi, \& Siti Norfakiah

Concepts in Malay and Aceh Traditional Houses

Laman (2014) affirmed that the architecture of the RK has a link and resemblance to the houses in Aceh and Makassar. Diaspora of people of the Nusantara region has brought together with them religion, culture and 'reconstruction' of their familiar environment in the new settlement. As a result, there is evidence of amalgamation of social culture that also affects the built environment.

Since Indonesia and Malaysia are within the equatorial climate belt region, there are a few attributes of both RK and RA that have been designed based on respects for the surrounding nature and also responds to the climatic context. For instance, the design for solar control, optimum ventilation and also the control of the thermal accumulation inside the house.

\section{RESEARCH METHODOLOGY}

The research methodologies employed are observation (through site visits), pictorial analysis and detail evaluation on the components of the houses. Site visits to several traditional houses in Central Perak and Aceh provided the fundamental data on the typology and layout of the houses. The site visits also provided information on cultural experience, scale, space utilization and feeling of space. On the other hand, pictorial analysis focuses on details and components of both house typologies. The mentioned methodologies in combination are basis for the detail evaluation on the house components; i.e. carvings. Data were collected from purposive sampling for both house types. The samples of RK in Bota, Perak (Figure 1) and RA from Banda Aceh (Figure 2) were chosen for the case study as both represent the traditional Muslim dwelling architecture for both regions. The character and features of both houses had been investigated and analysed according to the implementation of Islamic design, and also the sustainability concept of hablumminallah, hablumminannas and hablumminal'alam that has been discussed earlier. 
PLANNING MALAYSIA

Journal of the Malaysia Institute of Planners (2017)

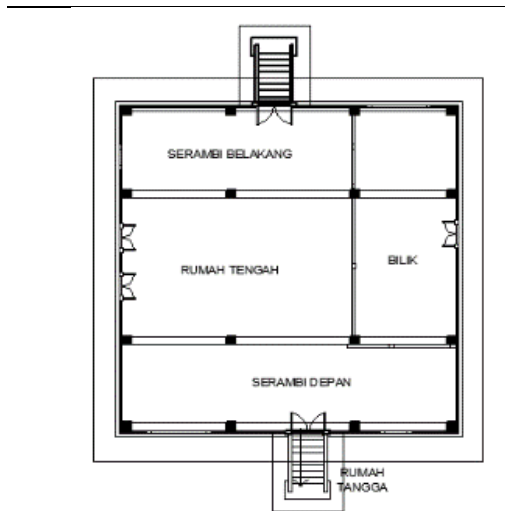

Plan (RK)

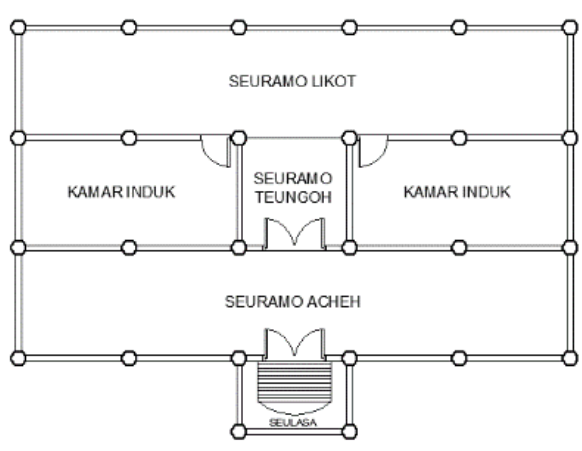

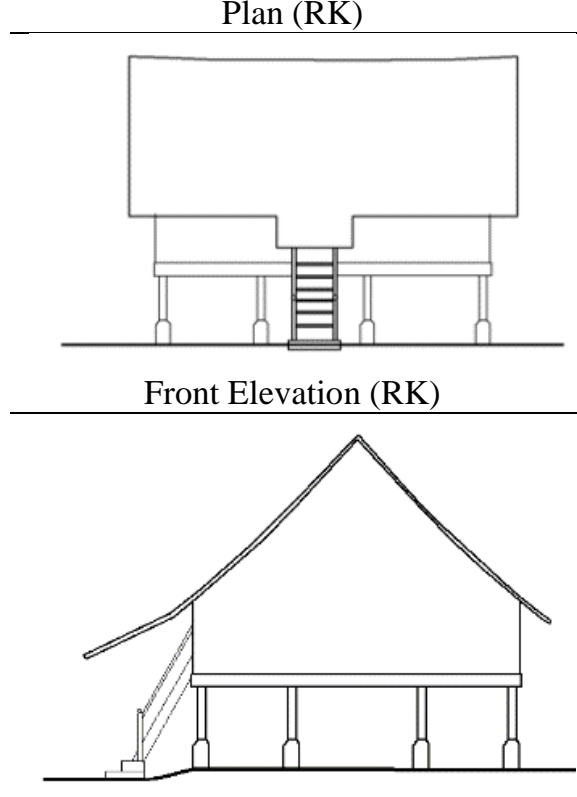

Side Elevation (RK)
Plan (RA)

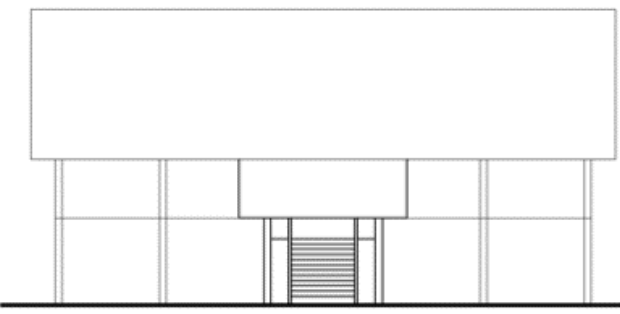

Front Elevation (RA)

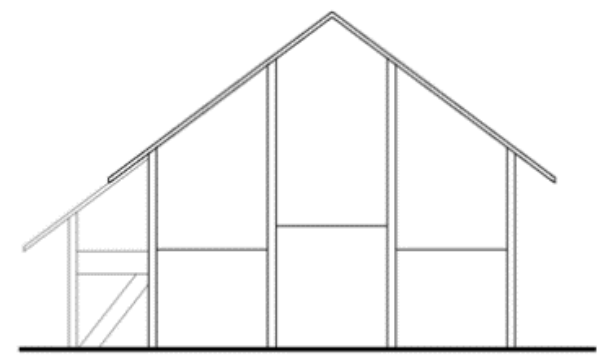

Side Elevation (RA)

Figure 2 Rumoh Aceh

\section{RESEARCH ANALYSIS AND FINDINGS}

The research analyses the case study houses in terms of the Islamic implementations (hablumminallah), social beliefs and activities (hablumminannas), and climatic influences (hablumminal'alam).

The traditional houses are fundamentally a reflection of hablumminallah or man submission to The Creator (Allah swt). As a vicegerent on earth, Man should take responsibility to fulfil his tasks as a servant; to worship and carry out 
Noor Hanita Abdul Majid, Zuraini Denan, Zaiton Abdul Rahim, Norwina Mohd Nawawi, \& Siti Norfakiah Concepts in Malay and Aceh Traditional Houses

duties towards man and environment. By performing these duties, man would have responded to the teachings of Islam. As stated in the Quran:

And I only created Jinn and men, that they may serve Me. No sustenance do I require of them, nor do I require that they should feed Me. For God is He Who gives (all) sustenance, Lord of Power, steadfast (for ever) [AdhDhariyat 51:56-58].

It is Allah that has created mankind as servants and provides sustenance for a living. Therefore, man should use available means to facilitate their duties as in building a shelter for themselves. Hence, the houses should accommodate the needs of man to carry out the basic requirements, most importantly daily prayers. Both RK and RA are aligned to the qiblah with the long sides elongated on the east-west axis (Nas \& Iwabuchi, 2008; Lim, 1987). The gables in RA are oriented East-West with the main door coming from North or South. According to Hindu belief, the entrance of the house should avoid facing towards sunset that resembles darkness and death. Due to Islamic influences, the gables were then oriented towards Makkah (Nas \& Iwabuchi, 2008). In some instances, there are entrances designed coming from the gable ends, but from the east so as not to disturb the praying direction that is towards the west. The spaces in both RK and RA also offer areas for congregational prayers beside other functions to support health and wellbeing of the occupants as stipulated in Islam.

Hablumminannas (the relationship between man and man) is highly reflected in the design of RK and RA. There are few characteristics of the houses that reflect the implementation of Islamic teachings. The characteristics comprise segregation between genders, female and male domains, and visual privacy.

The houses are inspired from the parts of man body while the measurements used during construction was also based on human anthropometric (Kamal, 2015; Wan Hashimah, 2005; Mohd Yusof, 2012). Table 1 shows the association of the human form to the houses and the body parts used for the measurements. The association to human form expressed the verticality concept. There is a vertical domain expression of the cosmos in the RA, and a horizontal expression of the segregation between male and female. The vertical principle as described by Nas \& Iwabuchi (2008) are related to the space underneath the house that is the realm of animals; the raised floor level represents the human life and the upper level with ancestors. 
Table 1 Measurement System in Construction of the Houses

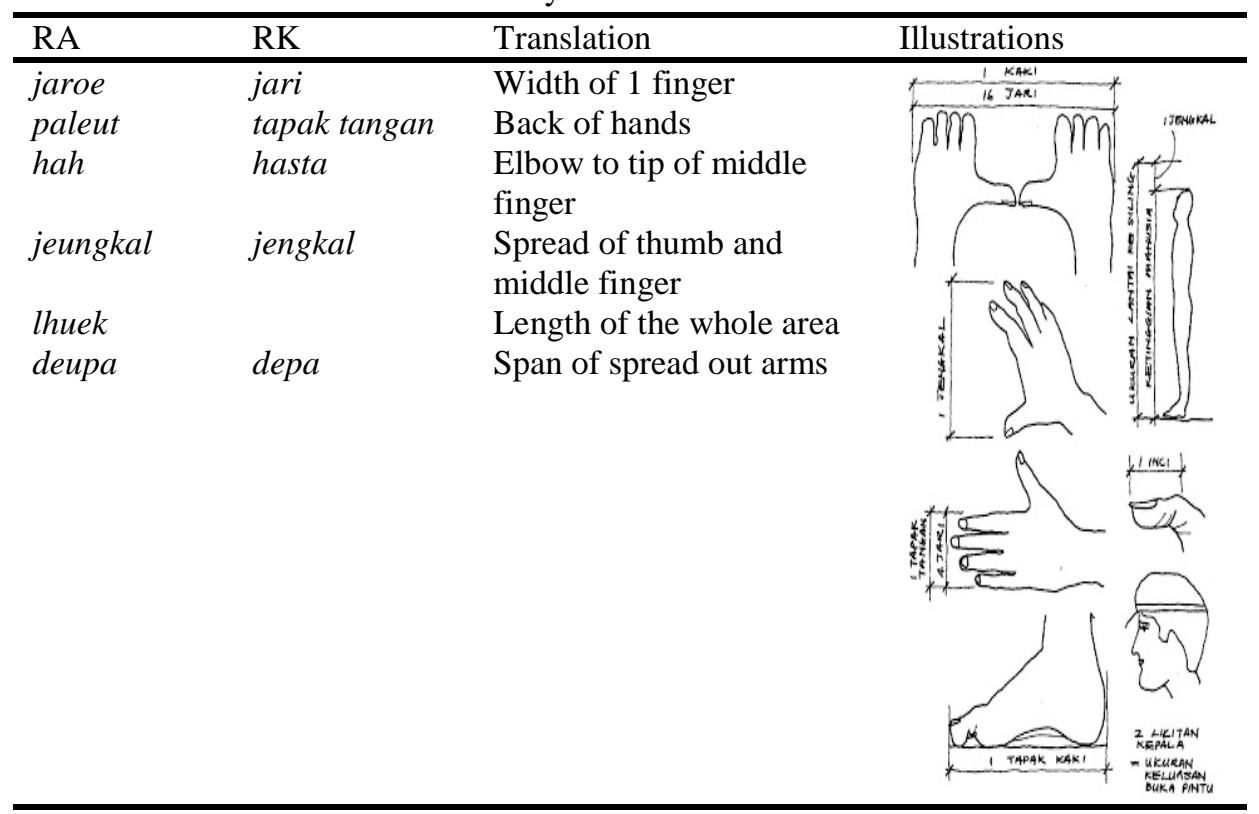

Source: Kamal (2015) \& Wan Hashimah (2005)

The lowest area, or the area underneath the house, that is associated with the realm of animals are practically used as a place of living during the daytime. It is also used as:

i. A storage of goods such as agricultural equipment, rice pounding block, rice, firewood.

ii. A place to rear animals. Waste are thrown here to be consumed by the animals or burnt to evade mosquitoes.

iii. A place of play for children or place to conduct work during daytime.

iv. A place for washing.

The vertical usage of RA is similar to most traditional Malay houses and other countries in the Southeast Asian region that are built on stilts. Case study visits to some areas in Perak provided evidence of the same usage of the spaces underneath the houses. The height of this space is between $1700 \mathrm{~mm}$ to $2500 \mathrm{~mm}$. The raised floor level is the living area for man to conduct daily activities and sleeping at nights. Lastly, the upper level that is regarded as sacred space in RA is the place of storage for valuable possessions in RA and RK. The profane spaces of the ground and raised level are the living areas that will be explained as horizontal expressions for both houses.

The horizontal expressions in RA and RK are mainly divided into three 
Noor Hanita Abdul Majid, Zuraini Denan, Zaiton Abdul Rahim, Norwina Mohd Nawawi, \& Siti Norfakiah Concepts in Malay and Aceh Traditional Houses

main areas that are illustrated in Table 2.

Table 2 Areas in RA and RK

\begin{tabular}{lll}
\hline Parts of the House & RA & RK \\
\hline Front area & seuramoe Acheh & Serambi depan \\
Middle area & seuramoe teungoh & Rumah tengah \\
Back area & seuramoe likot & Serambi belakang \\
\hline
\end{tabular}

The front areas are also the reception area for guests and geared towards the male gender in both RA and RK. People sit at these place on mats that are laid on the floor. Small feast and other activities are also held in this space. This space is a place for the male children to sleep at night. Male guests are confined to the front area and will not enter the middle area that is of a family and female domain (Lilawati et. al, 2006).

Both RK and RA have rooms in the middle house; in RA there are two rooms namely rumah inong (room for the couple of the house or married daughter) and anjong (room for unmarried daughters). On the other hand, RK mainly has only one room in the middle section. However, in both houses, the room is always attributed to the couple of the house and female children (married and unmarried). In both RK and RA, the central passage of the middle area is a domain of family members, married couple, treatment of sick family members and for the bathing of the dead (Kamal, 2015; Nur Azfahani, 2009). Similarly, the main house in RA (seuramoe teungoh) is a female or family domain where in some instances include rooms for unmarried female children.

The back area of both houses is female domain that has direct access for female guests. The seuramoe likot in RA is a sitting room and kitchen. This area has access to the courtyard where the well is situated. The rear access is a door with horizontal shutters for security. RK also has access to the rear area through serambi belakang. This access is for the female guests and also the access to the utilities in the house compound.

The architectural elements in RK and RA that are designed to satisfy the hablumminannas concept are door and window sizes. In both RA and RK, the door height is lowered $1,200-1,600 \mathrm{~mm}$ to send a message for the visitors to bow or bend their heads when entering the house. However, once the visitor has entered the house, the ceiling is high and gave a warm and welcome feeling.

It is common for uninvited male guests to be confined to the front steps or invited to the front area of RK and RA. In order to preserve privacy for the female occupants of the house, the houses were designed with small windows that limit the view to the interior of the house. At the same time, the small windows reduce light penetration and result to a darkened interior that supports privacy. Privacy is also achieved due to the darkened interior when male guests enter from the bright outdoors. The guests will take a few seconds to adjust to the 
dark interior and will allow the female occupants to retreat to the room or the back area, or to cover their awrah (body parts not allowed to be seen by nonmahram).

The relationship between man and environment (hablumminal 'alam) is clearly interpreted in both RK and RA. Both houses respond to the hot and humid climate that are manifested in raised form, elongated building form on the east and west axis, open plans, high ceilings, large roof overhangs and low thermal building materials alongside some other strategies to work with the climate. The basic idea of the traditional houses is to use the climatic factors to advantage and ameliorate harsh effects of the environment for the comfort of man. In agreement with the wisdom principles in traditional architecture, the houses were designed to optimize the given climatic conditions and the surrounding environment. The houses optimize natural ventilation to avoid heat and humidity accumulation; for example, RA and RK have the carved, or split gable ends on the wind path to facilitate cross and roof ventilation (Figure 3 and 4). While RK has a simple pitched roof ranging from 50-60 degrees that provides space for ventilation and cooling that support the thermodynamic process to flow out the heat from the inside to outside. Wall ventilation and raise floor help to avoid the heat accumulation, because of external or internal heat gain through gaps in the floorboards and walls in both RA and RK.

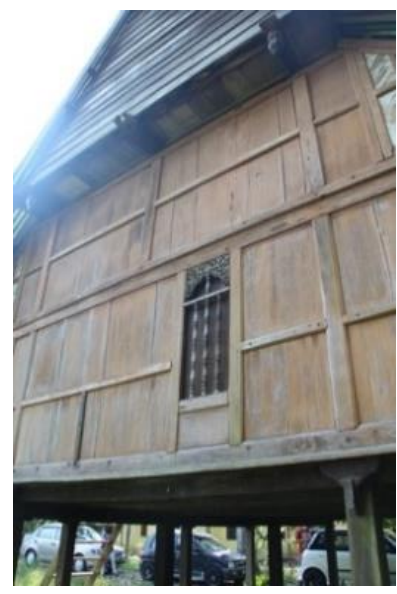

Figure 3: Gable Ends in

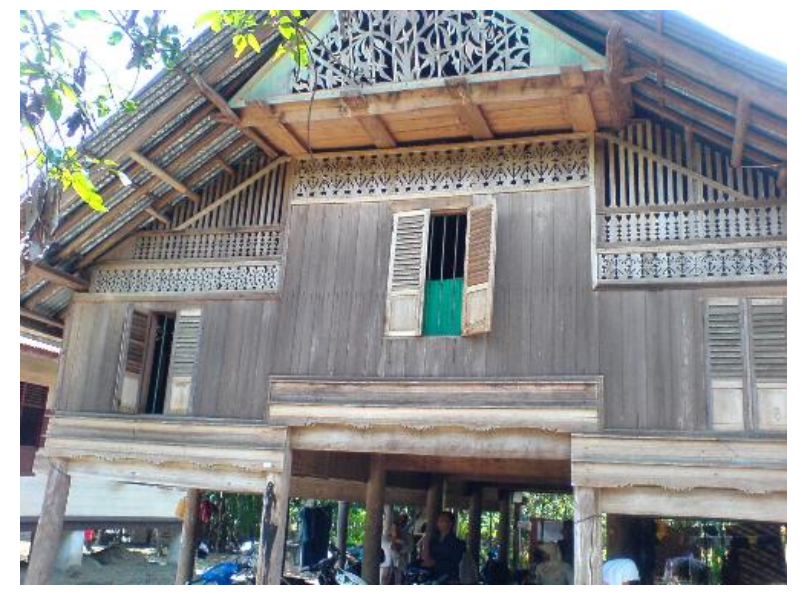

Figure 4 Carved Gable Ends in RA RK

The carvings implemented in RK and RA is another evidence of hablumminal'alam. Carvings on the houses depicted the entities from the surrounding environment depicting flora and fauna motifs (Figure 5). In older houses, there are carving motifs of fauna figures such as monkey, snake and bird that may have existed during pre-Islamic times in contrast to the floral motifs 
Noor Hanita Abdul Majid, Zuraini Denan, Zaiton Abdul Rahim, Norwina Mohd Nawawi, \& Siti Norfakiah Concepts in Malay and Aceh Traditional Houses

from plants that are allowable and in line with the teachings of Islam. Carvings are placed on the walls, doors, ventilation panels, openings, internal partitions and staircases (Sofyan, 2014) (Figure 6). The carvings motifs are mainly symmetrical and repeated pattern in the form of plant shoots, flora and crisscross patterns.

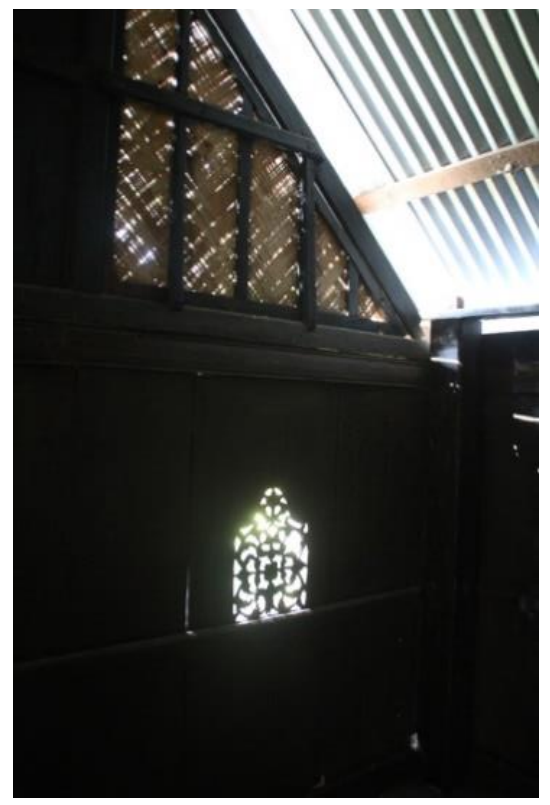

Figure 5 Carvings of Floral Motif at RK

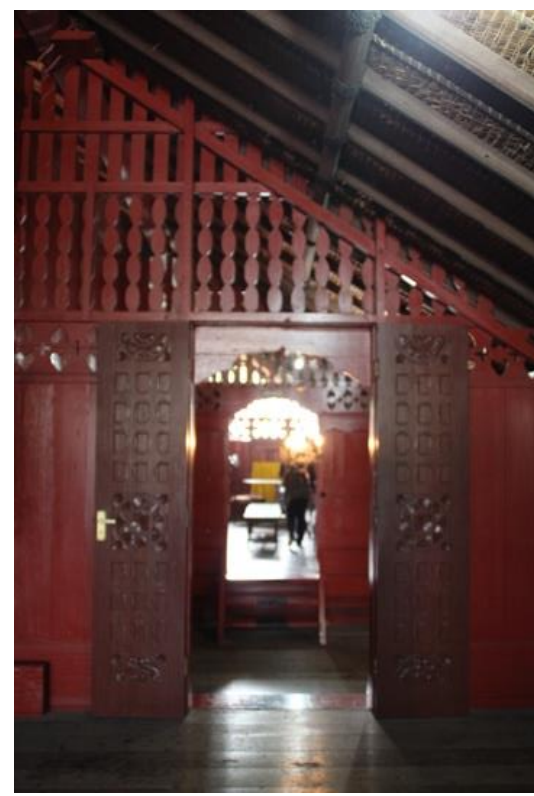

Figure 6 Carvings of Geometrical Motif on an Internal Partition at RA

The carvings are also a reflection of the owner's social status; the richer the carvings, the higher the status of the owner. Floral motifs were inspired from bunga Melati (Jasminum sambac), daun keor (M. oleifera), sulur pakis (diplazumesculentum), rebung (Dendrocalamus asper), kupula (mimusop elengi), pisang (Ravelana madagascariesis), bunga matahari (Helianthus anuus), rambutan (Nephelium lappacium) and pucuk labu (Cucurbita moschata). On the other hand, the fauna motifs were inspired from butterfly or kupu-kupu (Danaus sp.) and grasshopper or belalang (Oxy asp.). The application of carvings is a response to social-cultural background, climatic and geographical factor. The higher the status of the owner, the more ornate the carvings of the house. For example, the wall for RK are made of wood panels and carvings for higher ranking people, and weaved bamboo panels for commoners. 


\section{CONCLUSIONS}

The creative and innovative craftsmanship of these traditional dwellings can be seen through the application of the three concepts; hablumminallah, hablumminannas, and hablumminal'alam. The spatial design, structure and ornamentation aspects which created an identity and technology in these houses are to be appreciated and learned. The findings from the literature reviews and case studies suggest similarities in the realisation of the three mentioned sustainable concepts in RK and RA. On the other hand, the results also indicated differences in the houses due to social beliefs and activities. In conclusion, the overall findings confirmed the sustainability concepts adopted in the traditional Malay and Acehnese houses through adhering to Islamic guidelines, and sociocultural and climatic aspects.

\section{ACKNOWLEDGEMENTS}

This work was supported in part by ERGS13-010-0043. The authors would like to thank all involved in materialising this paper.

\section{REFERENCES}

Hutchinson, J. (2002). The vernacular 'Queenslander' part one - Prototype Houses. Australian Model Railway Magazine, 236(20), (11), 44-50.

Kamal, A. A. (2015). Keluhuran seni arsitektur rumoh Aceh. Seminar Nasional Inovasi Seni Kriya Bebasis Lokal Tradisi (National Seminar on Arts Innovation with Basis on Local Tradition). Jantho, Aceh Besar.

Kamaruzzaman, B.A., Ruzman, M. N., \& Mohd Yakub, M. Y. (2012). Konstruksi identitas Melayu dalam sejarah Aceh dan Penang. $6^{\text {th }}$ International Conference Indonesia-Malaysia, July 10-12, 2012, Surabaya, Indonesia.

Lilawati, A. W., Ahmad, A. G., Kamal, K. S., \& Syed Mustafa, S. A. H. (2006). Rumah Kutai: warisan senibina Melayu negeri Perak yang semakin pupus. In Proceedings of the $2^{\text {nd }}$ Asean Post Graduate Seminar in Built Environment. Kuala Lumpur, Malaysia.

Lim, J. Y. (1987). The Malay house: rediscovering Malaysia's indigenous shelter system. Institut Masyarakat.

Mohd Yusof, A. (2012). Warisan Senibina Melayu Terengganu. Kuala Terengganu: Yayasan DiRaja Sultan Mizan.

Nas, P. J. M., \& Iwabuchi, A. (2008). Aceh, Gayo and Alas: traditional house form in special region of Aceh. Leiden: KITLV Press.

Nur Azfahani, A. (2009). Traditional Malay houses in Malaysia. Retrieved March, 2016 from http://nurazfahaniahmad.blogspot.my/2009/01/rumah-penghulu-abuseman.html

Seri Laman (2014). Rumah-rumah traditional di Semenanjung Malaysia. Retrieved March, 2016 from http://serilaman.sekolah4u.com/rumah-rumah-tradisional-disemenanjung-malaysia/

Sofyan, S. (2014). Ornaments of flora and fauna on traditional Aceh house. Journal Natural, 14(2), 33-35. 
Noor Hanita Abdul Majid, Zuraini Denan, Zaiton Abdul Rahim, Norwina Mohd Nawawi, \& Siti Norfakiah Concepts in Malay and Aceh Traditional Houses

Spahic, O. (2009). A conceptual framework for sustainability in Islamic architecture: the significance of the concepts of man and environment. In Proceedings of the International Symposium on Construction in Developing Ec onomies: Commonalities among Diversities. Penang, Malaysia.

Versus (2016). Vernacular heritage sustainable architecture. European Research Project. Retrieved March, 2016 from http://www.esg.pt/versus/

Wan Hashimah, W. I. (2012). Houses in Malaysia: fusion of the east and the west. Skudai, Johor: Penerbit Universiti Teknologi Malaysia. 